\title{
O QUILOMBISMO: UMA EXPRESSÃO DA FILOSOFIA POLÍTICA AFROPERSPECTIVISTA ${ }^{1}$
}

\section{KILOMBISM: AN EXPRESSION OF AFROPERSPECTIVE POLITICAL PHILOSOPHY}

\author{
Lorena Silva Oliveira ${ }^{2}$ \\ Recebido em: 07/2019 \\ Aprovado em: 09/2019
}

\begin{abstract}
Resumo: O presente artigo intenta fazer uma análise introdutória sobre o que é a Filosofia Política Afroperspectiva para, a partir dessa concepção, analisar em que medida o Quilombismo, movimento e projeto político de sociedade, proposto pelo filósofo Abdias Nascimento, pode ser compreendido como expressão de uma filosofia política afro-brasileira (afroperspectivista). Parte-se do princípio que a população negra é, historicamente, vítima de um sistema político ágorofóbico, que silenciou sua agência política e que a filosofia afroperspectivista vem resgatar a agência e memória cultural, intelectual e política dos povos diaspóricos. Em tom conclusivo, o presente texto apresenta o pensamento de Abdias Nascimento como expressão da filosofia política afro-brasileira ao evidenciar o caráter libertário e revolucionário do projeto de Estado Nacional Quilombista. Reitera a importância de a filosofia política resgatar e investigar outros projetos de sociedade que tenham como eixo a verdadeira liberdade dos povos, sobretudo, o povo preto e indígena se, de fato, queremos um projeto de futuro, de sociedade em que todos possam bem viver.
\end{abstract}

Palavras-chave: Filosofia Política Afroperspectivista. Projeto. Agência Negra. Quilombismo.

\begin{abstract}
This article intends to make an introductory analysis of what is the Afroperspective Political Philosophy, from this conception, to analyze to what extent the Quilombismo, movement and political project of society, proposed by the philosopher Abdias Nascimento, can be understood as an expression of a Afro-Brazilian (Afro-Perspective) political philosophy. It is assumed that the black population has historically been the victim of an agorophobic political system that has silenced its political agency, and that Afro-Perspective philosophy rescues the agency and cultural, intellectual and political memory of diasporic peoples. In conclusion, the present text presents the thought of Abdias Nascimento as an expression of Afro-Brazilian political philosophy by highlighting the libertarian and revolutionary character of the Quilombista National State project. Reiterates the importance of political philosophy rescuing and investigating other projects of society that have as their axis the true freedom of peoples, especially the black and indigenous people, if indeed we want a future project of society in which everyone can live well.
\end{abstract}

Keywords: Afroperspectivist Political Philosophy. Project. Black Agency. Quilombismo.

\footnotetext{
${ }^{1}$ Este texto é fruto da minha atual pesquisa de doutorado, que pretende pensar uma Filosofia Política Afroperspectivista, isto é: a partir de autores africanos e diaspóricos.

${ }^{2}$ Doutoranda em Filosofia - PPGF/UFRJ. Co-coordenadora do Núcleo de Pesquisa em Filosofia Política Africana, do Laboratório de Africologia e Estudos Ameríndios -GERU MAA/UFRJ. Pesquisadora Associada ao Núcleo de Estudos Afro-brasileiros - NEAB/UFU. Bolsista do Conselho Nacional de Desenvolvimento Científico e Tecnológico (CNPQ). E-mail: professoralorenaoliveira@gmail.com.
} 


\title{
Filosofia política afroperspectivista: considerações
}

\author{
Tu que és o senhor dos \\ caminhos da libertação do teu povo \\ sabes daqueles que empunharam \\ teus ferros em brasa \\ contra a injustiça e a opressão \\ Zumbi Luiza Mahin Luiz Gama \\ Cosme Isidoro João Cândido \\ sabes que em cada coração de negro \\ há um quilombo pulsando \\ em cada barraco \\ outro palmares crepita \\ os fogos de Xangô iluminando nossa luta \\ atual e passada
}

Padê de Exu Libertador-Abdias Nascimento ${ }^{3}$

Carxs leitorxs, intento nessas primeiras linhas apresentar alguns pensamentos que venho nutrindo acerca do que considero ser ou dever ser uma Filosofia Política Afroperspectivista. O filósofo Renato Noguera define a afroperspectividade ${ }^{4}$ como uma abordagem filosófica pluralista que reconhece diversos territórios epistêmicos e está

[...] empenhada em avaliar perspectivas e analisar métodos distintos e com uma preocupação especial para a reabilitação e incentivo de trabalhos africanos e afrodiaspóricos em prol da desconstrução do racismo epistêmico antinegro e da ampliação de alternativas para uma sociedade intercultural e não hierarquizada. Em outros termos, um tipo de ação afirmativa no campo epistêmico (NOGUERA, 2011, p.35).

Neste sentido, é uma abordagem que busca por perspectivas afirmativas, que reconheça, em todos os âmbitos, os povos historicamente destituídos do direito de participarem enquanto agentes e condutores da sua própria história. Para mais, é uma abordagem filosófica que busca trilhar novas possibilidades e proporcionar a ampliação de alternativas para a construção de uma sociedade que não possua como estrutura, no campo intelectual e prático, o racismo.

Assim, uma das principais importâncias da afroperspectividade está na possibilidade de

\footnotetext{
${ }^{3}$ Esta poesia, dentre outras, de autoria de Abdias Nascimento podem ser acessadas no site do IPEAFRO. Disponível em <http://www.abdias.com.br/poesia/poesia.htm> Acesso em 10 jun. 2019

${ }^{4}$ Conforme Renato Noguera "A expressão afroperspectividade é herdeira de um debate a respeito da inclusão de vozes africanas e ameríndias nas áreas de filosofia e educação. Dentre as leituras e referências que delineiam o surgimento da abordagem afroperspectivista podemos destacar, a antropóloga guarani nhandeva Sandra Benites; a antropóloga branca Tânia Stolze Lima; a socióloga nigeriana Oyeronke Oyewumi; o filósofo quilombola Antônio Bispo dos Santos; o xamã e filósofo yanomami Davi Kopenawa; o pan-africanista e sistematizador da afrocentricidade Molefi Asante; o cientista social e ativista negro Abdias do Nascimento; o antropólogo branco brasileiro Eduardo Viveiros de Castro e os pensadores brancos franceses Gilles Deleuze e Félix Guattari'(NOGUERA, 2018, pp. 627-628).
} 
esta trazer à tona

[...] alternativas e perspectivas quase desconhecidas que podem sugerir argumentos, ponto de vista, ideias e conceitos em favor de caminhos inusitados criativos e propositivos sobre ética, politica, ciência, religião, sexualidade, educação, relações etnicorraciais e de gênero, entre outros assuntos e temas (NOGUEIRA, 2011, p.36).

Logo, na esteira da afroperspectividade como eu tenho concebido uma Filosofia Política Afroperspectivista? Tenho refletido que uma Filosofia Política em Afroperspectiva, de modo geral, está preocupada em pluriversalizar a filosofia, ao buscar deslocar o Ocidente do centro para que outros povos - em especial pensadores e filósofos/as africanos/as, afrodiaspóricos/as, dentre outros comprometidos com o combate ao racismo, ao imperialismo, ao capitalismo, à necropolítica, o neocolonialismo e todos os tipos de opressões - possam contribuir nos pensares sobre como desfazer as hierarquizações que advém desses processos.

A Filosofia Política Afroperspectivista compreende a falaciosidade do universalismo das ciências. Por este fato, é uma filosofia que está preocupada com o reconhecimento da agência política, intelectual, econômica e cultural dos homens e mulheres africanos no continente e nas diásporas. Sendo assim, é uma filosofia que está engajada com a Liberdade, pois a mesma é um derivado do pensamento africano que, conforme Ngoenha (2004), está assentado sobre um único eixo: a Liberdade.

Nos diz Severino Ngoenha, em sua obra Os tempos da filosofia: filosofia e democracia moçambicana que

O substrato filosófico do pensamento africano é, sem dúvida, a busca da liberdade, devido à situação categorial oprimido/escravo/colonizado/subdesenvolvido na qual os povos africanos se encontram a seguir ao encontro/choque com o ocidente (NGOENHA, 2004, p.74).

Conquanto, essa liberdade não é de cunho metafísico ou moral. A liberdade ambicionada é uma liberdade de natureza política, pois mesmo após a independência nos países africanos e a abolição da escravatura nas diásporas, devido ao racismo estrutural, o sistema político e econômico continua desumanizando, escravizando e tutelando política, econômica e ideologicamente a população africana no mundo, ou seja, continua nos mantendo colonizados.

Neste sentido, afirmo que o paradigma libertário, considerado critério de avaliação sobre o que é ou não filosofia africana para Ngoenha, baliza o que considero por Filosofia 
Política Afroperspectivista, por acreditar que esta filosofia deve ser julgada como tal, a partir da conclusão sobre em que medida ela busca maximizar ou não o campo das liberdades, ou seja, a emancipação : autogestão e autodeterminação dos africanos no continente e na diáspora.

Tal posição, se justifica, pelo fato de que, a busca pela liberdade está concatenada com a compreensão de filosofia africana, trabalhada pelo filósofo Ngoenha na obra Filosofia Africana: Das Independências às Liberdades (1993), que vem nutrindo minhas reflexões. Nela, observamos que para o filósofo, a filosofia africana tem um compromisso com o futuro, e não deve ter os olhos voltados, apenas, em direção ao passado, mas ao futuro, pois ela é "um projecto do futuro" (NGOENHA, 1993, p.93), aberto e descontínuo. Uma investigação perene, que se faz através de textos.

Logo, ao afirmar que "Na existência tudo se faz em função do futuro" (Idem, p.11) e que a filosofia africana é um projeto do futuro, compreendo que a Liberdade é para o autor o fator primordial que deve constituir a nossa contínua elaboração filosófica, dado ser a busca pela liberdade, em todas suas expressões, o principal fator que nos possibilitará contribuir nos pensares sobre como construir outros modos de vida no presente e no futuro.

Portanto, cabe à filosofia mostrar as luzes que iluminem o caminho dos povos africanos para a maximização dos campos das suas liberdades políticas, sociais, culturais e econômicas, contribuindo na edificação de uma sociedade futura libertária, democrática e soberana em que não tenhamos mais que "executar futuros inventados por outros e em beneficio deles"(NGOENHA, 1993, p.10).

Mas, o futuro é entendido como o conjunto de projetos, de possíveis, de esperanças, de liberdades, que possui três aspectos:

[...] o primeiro, é já a sua antecipação no presente; o segundo, é um futuro que será em parte nosso e em parte dos outros; terceiro, (um futuro do futuro) que será dos que ainda não nasceram, um futuro que não podemos e nem sequer devemos predeterminar na sua originalidade, mas que condicionamos de uma certa maneira; e desta forma somos responsáveis. A relação com o futuro não é uma relação com o inexistente (NGOENHA, 1993, p. 133).

O filósofo acredita que o futuro é o agora, o pôr vir que diz respeito aos outros viventes e aos que nem nasceram. Logo, em todos os seus aspectos o futuro deve ser encarado pela filosofia africana com responsabilidade, pois nele está a possibilidade de construir uma nova história, uma nova sociedade, vez que a história é feita por nós, homens e mulheres, e temos responsabilidade sobre o tipo de história e futuro que desejamos e projetamos para todxs 
viventes presentes ou não.

As reflexões realizadas pelo filósofo moçambicano fez com que eu refletisse sobre a importância da população negra brasileira projetar seu futuro a partir de seus referenciais, mas não somente, fez com que eu refletisse sobre o quão legitimo é "que nos interroguemos sobre o lugar da filosofia na problemática da construção do futuro" (NGOENHA, 1993, p. 8).

É evidente que vivenciamos/executamos, historicamente, projetos de futuro eurocentrados que não condizem com as concepções de mundo e modo organizacional que os povos africanos e afrodiaspóricos advém. Por este fato, considero urgente a filosofia política contemporânea assumir a responsabilidade de retirar o projeto do Ocidente do centro e contribuir na busca e elaboração de alternativas de projetos de sociedade que, no mínimo, estejam o mais próximos possíveis da maximização das Liberdades e da Igualdade para os povos subalternizados, pois o projeto ocidental, genocida, já demonstrou que é ruim para todos povos colonizados e parte deste projeto foi assinado pela filosofia.

Assim sendo, a Filosofia Política Afroperspectivista deve estar engajada na construção de mundos habitáveis. Ela deve servir de instrumento para transformação da nossa situação atual. Logo, cabe a ela investigar, refletir, construir, sobretudo, recuperar a memória da agência política negra buscando evidenciar alternativas já existentes, - que são combativas aos projetos de sociedade genocidas, colonizadores, imperialistas, latifundiários, supremacistas, que foram a nós impostos pelo Ocidente - e verificar, em que medida, tais alternativas podem ser consideradas inspirações e possibilidades revolucionarias, nos atuais dias de destruição ${ }^{5}$.

Amparada em Abdias do Nascimento (2019), acredito que a Filosofia Política Afroperspectivista deve ser um campo do saber sistematizado e consistente que esteja comprometido com a descolonização mental e a Liberdade, pois como este filósofo político, acredito que

O conhecimento cientifico que os negros necessitam é aquele que os ajude a formular teoricamente - de forma sistemática e consistente - sua experiência de quase quinhentos anos de opressão. Haverá erros ou equívocos inevitáveis em nossa busca de racionalidade do nosso sistema de valores, em nosso esforço de autodefinição de nós mesmos e de nosso caminho futuro. Não importa. Durante séculos temos carregado o peso dos crimes e dos erros do eurocentrismo 'cientifico', os seus dogmas impostos em nossa carne como marcas ígneas da verdade definitiva. Agora devolvemos ao obstinado segmento 'branco' da sociedade brasileira as suas mentiras, a sua ideologia de surpremacismo europeu, a lavagem cerebral que pretendia tirar nossa

\footnotetext{
${ }^{5}$ Refiro-me ao genocídio da população negra, projeto arquitetado pelo Estado brasileiro para aniquilar esse segmento da população.
} 
humanidade, a nossa identidade, a nossa dignidade, a nossa liberdade. Proclamando a falência da colonização mental eurocentrista, celebramos o advento da libertação quilombista (NASCIMENTO, 2019, pp.287-288)

Em consonância com o pensamento de Abdias Nascimento e Severino Ngoenha ratifico ser tempo da filosofia, que alicerçou o pensamento racista, contribuir, interdisciplinarmente no processo de construção de um projeto de futuro emancipatório para todos os povos, que foram historicamente desumanizados, explorados, subalternizados e negligenciados de participarem da elaboração deste projeto de sociedade ocidental, que por sinal, nunca os considerou, verdadeiramente, cidadãos e partícipes da história.

Neste sentido, é tempo da filosofia brasileira investigar, reconhecer e tornar público a existência de pensamentos filosóficos pretos e indígenas que há tempos demonstram e ressoam a necessidade de outro modo organizacional, se de fato queremos bem viver.

Investigar e evidenciar caminhos propositivos pretos e indígenas é buscar dessacralizar este projeto de sociedade brasileira ágorafóbica ${ }^{6}$ em que uma elite, branca, detém o poder sobre o povo (dominação), e impede o exercício de ágora-filia política que garante que as pessoas sejam autônomas e tenham o poder de decidirem sobre o que desejam (DUPUIS-DÉRI, 2019).

Penso que, parte do processo de dessacralização desse projeto ágorofóbico, passa pela necessidade de reconstruirmos no presente, uma sociedade dirigida ao futuro, que leve em conta o que é útil e positivo no acervo do passado, que muitas vezes não conhecemos, mas que existe e, por isso mesmo, foram negligenciados à população, por ter a capacidade de colocar em risco o status quo da elite dominante.

O positivo, por exemplo, exerce um papel fundamental nesse processo, pois a Filosofia Política Afroperspectivista é uma filosofia comprometida com a reontologização e liberdade do povo africano e diaspórico e este processo requer o reconhecimento/representatividade positiva do povo negro que contribua no fortalecimento de nossa autoestima para combatermos o que a colonização nos legou: o auto - ódio, fator que prejudica o nosso agenciamento intelectual, político, econômico.

Neste sentido, resgatar o útil e positivo é o exercício da filosofia afroperspectivista, já que o que nos chega do acervo do passado, através dos livros e grandes mídias é a imagem deturpada do povo negro e indígena, tidos ora como passivos e submissos aos desejos da elite ora como nocivos e prejudiciais a um país que se lançava ao desenvolvimento.

\footnotetext{
${ }^{6}$ Resumidamente, podemos compreender por ágora-fobia política “o medo e o ódio das pessoas reunidas na ágora para deliberarem e governarem a si mesmas; por outro lado, a ágora-filia política, isto é, o amor pelas pessoas reunidas na ágora para se autogovernarem" (DUPUIS-DÉRI, 2019, p.5).
} 
Tais imagens prejudicaram, consideravelmente, a participação desses povos na vida política e ainda preenche e prejudica o imaginário sócio-político brasileiro, que tende a acreditar e ainda difunde a falsa ideia de que a população negra nunca resistiu nem propôs mudanças.

Gisele Santos (2002) em sua obra A invenção do Ser Negro: um percurso das ideias que naturalizaram a inferioridade dos negros nos apresenta uma previa das ideias que foram construídas sobre os negros durante a escravidão e no pós-abolição com o intuito de construir imagens deturpadas da população negra, de modo que estes, no imaginário coletivo, não alçassem as características de cidadãos.

Segundo a autora, nos jornais do século XIX circulavam ideias de cunho racista que buscavam dar ares de verdade às teorias cientificas eugenistas, ao retratar as pessoas negras, em todas as seções, como algo perigoso, animalesco, lascivo, violento, imoral, dentre outras características que irão marcar o corpo negro, até os dias hodiernos, como corpos governáveis. Conforme Santos,

A reprodução no Brasil de todos os preconceitos europeus se dava letra a letra. A perseguição aos africanos que eram símbolos de barbárie, de decadência cultural e de inferioridade era retratada nos jornais da época de forma corriqueira entre uma e outra notícia. Lidas e relidas com certa frequência, essas noticiais em vez de informar a população, disseminavam teorias racistas. Do escravo, artigo vendido ou comprado, ao marginal negro não havia muito espaço. O negro será retratado nos jornais: nas seções cientificas, como objeto de estudo ou comprovação das teorias racistas; nas seção de notícias, ora assassino, ora fugitivo, ora como um ser incapaz de viver em sociedade cometendo graves erros por ignorância, ora por suas práticas de feitiçaria ou canibalismo, ora por usa degeneração moral; na seção de anúncios, como mercadoria que se compra e vende, procurada ou encontrada; na seção de contas, como um semi-homem com características pouco civilizadas. Não podemos nos esquecer das seções policiais e dos obituários, em que a figura do negro era uma constante: é aquele que mata e também aquele que morre de forma quase sempre violenta (SANTOS, 2002, pp.128, 129).

A autora, demonstra-nos que a difusão de uma visão negativa sobre o negro tinha por intuito, também, representá-lo como um indivíduo que se distanciava dos padrões de comportamento que a República requisitava. Difundia-se a ideia de que os negros eram pessoas em que não se podia confiar, por serem compreendidos como sujeitos sem estrutura moral, psíquica e social.

Portanto, buscou-se no período de advento da República inverter a imagem do negro de pacífico e passivo para um negro nocivo e prejudicial a um país que buscava o desenvolvimento. Como salienta a autora "ao ressaltar o caráter selvagem e em nada propenso à civilização do 
negro tentava-se provar que ele jamais poderia ser um cidadão (como o branco, como o imigrante) (SANTOS, 2002, p.130).

Logo, a entrada do povo preto e indígena no organismo político era considerado algo que iria "não somente retardar, mas praticamente entravar o nosso desenvolvimento cultural" (apud FISCHMANN, 2001 apud CARNEIRO, 2005, p. 109). É evidente nesta passagem, os reflexos do pensamento racista e do discurso do racismo científico, que defendia ser a interação das raças fator condicionante para o não desenvolvimento cívico de uma sociedade.

Como também, fica evidente que "qualquer elite necessariamente sofre de ágora-fobia política como resultado de sua posição socialmente dominante, e a ágora-fobia política é em si uma emoção temerosa que prejudica a racionalidade potencial de qualquer elite" (DUPUISDÉRI, 2019, p.12).

Fato é que, a construção e disseminação dessas ideias racistas, animalescas e violentas sobre a população negra tinha o objetivo evidente de colocar esta população à margem da sociedade e fora do exercício político dominante, vez que qualquer tipo de ameaça à supremacia branca - como a interação de africanos e seus descendentes no seio político da sociedade, ou o simples fato destes acreditarem em sua cidadania e exigir direitos iguais - poderia colocar em risco os interesses políticos do Estado, a saber: o desenvolvimento econômico, cultural e social da raça branca, a qual o Estado é protetor da integridade.

Instaurou-se, neste ínterim, com o objetivo de impedir o florescimento da população negra no corpo social e político, um projeto de embranquecimento do país que não cabe, neste trabalho, debruçar-me sobre o tema. Contudo, é imprescindível fazer algumas considerações sobre o papel exercido pelos meios de comunicação e o conhecimento cientifico para a manutenção do sistema escravagista, da supremacia branca, exclusão da população negra e indígena da arena política nos pós abolição, dentre outras opressões.

Ao observar o percurso das ideias racistas que contribuíram no processo de construção de um imaginário social que excluísse os povos negros e indígenas do status de cidadãos, verifica-se a relação entre poder e saber e o quanto ambos expressam o que o historiador e cientista político Wallace de Moraes (2018) conceitua como governança política $e$ sociocultural. ${ }^{7}$

\footnotetext{
${ }^{7}$ Wallace de Moraes expõe-nos em sua obra Governados por quem? Diferentes plutocracias nas histórias políticas de Brasil e Venezuela, a existência de cinco governanças institucionais (econômica, político, sociocultural, jurídica e penal) Considero serem todas chaves de leitura para compreendermos a história da população negra e indígena na sociedade brasileira. No entanto, dado os limites deste trabalho abordarei apenas as governanças institucionais política e sociocultural.
} 
Em um governo plutocrático, ou seja, em um "sistema político governando por um grupo de pessoas que detém o poder econômico ou está a seu serviço" (DE MORAES, 2018, pp.39-40) é condição necessária para a manutenção do projeto de sociedade que os favoreça, que estes utilizem do saber cientifico para legitimarem suas ações e controle político.

Logo, para que se estabeleça uma sociedade de controle em que a governança política e econômica se mantenha supremacista branca e garanta a manutenção de seus privilégios, advindos, historicamente, da exploração dos povos não-brancos, é necessário determinar quais saberes podem e devem ser difundidos como verdades.

Com Michel Foucault compreendemos que saber e poder possuem uma relação intrínseca. Consequentemente, a produção cientifica, sobretudo as teorias raciais do século XIX, não estavam desatreladas dos interesses dos que possuíam e ainda possuem o poder econômico e político no Brasil e no mundo.

Ao difundir-se ideias e empenhar-se para a construção de uma imagem pejorativa do negro, seus saberes e práticas, os governantes- dentre eles os intelectuais executores desse projeto - visavam legitimar e justificar o status quo, que significa a branquitude 8 como governadora ideal de todos os povos. Esse tipo de tática é conceituado dentro da governança sociocultural como governança sociocultural ideológica, por ser um meio de buscar o adestramento da população pela via ideológica (DE MORAES, 2018).

Evidentemente, atrelada à governança sociocultural ideológica está a governança sociocultural do saber escolar que tem como local privilegiado as escolas e universidades que possuem muitos professores formatados, propositalmente, para retroalimentarem um discurso a favor do estabelecido, com a chancela do "saber cientifico" que, historicamente, esteve a serviço da branquitude (governantes) e seus projetos colonizados/exploradores.

Mas, conforme o historiador, os governantes mantem as opressões/governanças sociais acadêmica-cientifica, "pois simultaneamente cometem o epistemicídio contra as produções revolucionarias e populares, colocando-as como saberes sujeitados, inferiores, errados" (DE MORAES, 2018, p.64) $)^{9}$.

Neste sentido, que é importante compreendermos a proposição de Abdias Nascimento (2019) ao ressaltar a necessidade de resgatarmos do acervo do passado o que for útil e positivo

\footnotetext{
${ }^{8}$ Sobre o conceito de branquitude e suas implicações, Cf.: CARDOSO, Lourenço. A branquitude acrítica revisitada e a branquidade. Revista da ABPN, Florianópolis, v. 6, n. 13,p. 88-106, mar./jun. 2014.

9 De acordo com a filósofa Sueli Carneiro, o epistemicídio deve ser compreendido como um processo que "fere de morte a racionalidade do subjugado ou a sequestra" (CARNEIRO, 2005, p.97). O epistemicídio destitui de razão os indivíduos sobre os quais esta operação se volta, constituindo um processo de indigência cultural por deslegitimar a possibilidade da produção de conhecimento pelos povos subjugados.
} 
para projetarmos o futuro, pois fomos/somos vítimas de um processo que o filósofo em sua obra “O Quilombismo”, conceitua como mentecídio ${ }^{10}$, ou seja, um processo de lavagem cerebral que visa entorpecer ou castrar a capacidade de raciocínio dos indivíduos negros, que nos impossibilitou e impossibilita conhecermos nossas produções revolucionarias, que poderia nos guiar rumo a um futuro melhor.

Para o autor, o mentecídio, essa lavagem cerebral, é uma ferramenta de controle social que contribui, significativamente, para a estratégia de aniquilamento total da população negra (NASCIMENTO, 1980). Por isso que encontramos com facilidade o que nos desfavorece, nos mata e busca manter o estabelecido, no acervo disponibilizado pela governança ideológica. Diante disso, sua proposição sobre a necessidade um conhecimento cientifico que nos ajude a sistematizar, consistentemente, nossa história/experiencia/agenciamento, de séculos (mais de quinhentos anos), é de extrema lucidez e urgência para uma existência com dignidade.

Por este fato, convoco uma Filosofia Política em Afroperspectiva para nos ajudar nessa missão futuro de investigação, resgate, reconhecimento, construção e sistematização da atividade política/intelectual do povo preto no continente africano e em suas diásporas. Como fora dito, esse processo é vital para o fortalecimento da subjetividade, para o processo de reontologização da população negra e para a construção de um processo revolucionário, que destrua essa estrutura racista e capitalista em que vivemos.

A exposição/apresentação/acesso da população negra a um conhecimento que resgate nossa memória, para que tenhamos referenciais positivos e reais, de organização social, amparado em nossos valores - que não são de exploração e apropriação privada dos recursos - além de combater o epistemicídio e o mentecídio, pode (assim acredito) gradualmente, despotencializar o projeto de sociedade ocidental que é ágorofóbico, racista, capitalista e necropolítico, por dar a nós, população preta, a consciência histórica e política de que os governantes, historicamente estabelecidos, só estão onde estão, sobretudo, porque buscaram apagar a nossa memória e enfraquecer, pelo genocídio mental, espiritual, cultural, político, nossa potência.

Em uma via combativa ao mentecídio, intento nas próximas linhas apresentar uma proposta preta de organização social que é comprometida com um projeto de sociedade que combata todos os tipos de governanças, sejam elas sociais e/ou institucionais; e resgata do acervo do passado o que é útil e contribui para o processo emancipatório da população negra.

\footnotetext{
${ }^{10}$ Este conceito aparece na obra "O Quilombismo" na edição de 1980, da Editora Vozes, na página 25. Na edição de 2019 o termo mentecídio é subtraído, mas a ideia permanece na página 45.
} 
Apresento o Quilombismo, um projeto de sociedade cunhado pelo filósofo político Abdias Nascimento, essencial para o hall do pensamento político afrodiaspórico, que considero ser a expressão da existência de uma filosofia política afro-brasileira (afroperspectivista) que tem o paradigma libertário como eixo.

\section{O Quilombismo}

Antes de adentrar à proposta de sociedade conceituada como Quilombismo, é preciso conhecermos, ainda que brevemente, Abdias Nascimento (1914-2011) ${ }^{11}$.

Abdias foi um homem negro, pan-africanista, ativista social, economista, artista plástico, poeta, dramaturgo e político brasileiro, comprometido com a defesa da cultura e igualdade para a população afrodescendente no Brasil. É autor de várias obras, dentre elas: $O$ negro revoltado(1968), O genocídio do negro brasileiro (1978), Sortilégio - Mistério Negro (1978), O Quilombismo (1980), O Brasil na mira do Pan-Africanismo (2002), que expressam sua imersão qualificada na análise dos mecanismos do racismo e seu potencial colaborativo no processo de compreensão da realidade de negros e negras na sociedade brasileira.

Desde jovem, Abdias estava engajado na vida política. Em 1930 participa do Frente Negra Brasileira, uma das principais organizações a exigir igualdade de direitos e a participação dos negros em nossa sociedade. A organização desenvolvia atividades de caráter político, cultural e educacional, tornou-se partido político, no entanto, com a ditadura do Governo Vargas, foi obrigada a encerrar suas atividades.

Em 1944 cria o Teatro Experimental do Negro que, além de propagar e desenvolver a dramaturgia negra, possuía atividades que contribuíam para a consolidação da cidadania dos atores, por meio da alfabetização e conscientização deste sobre a situação da população negra no Brasil. O TEN (Teatro Experimental do Negro) rompeu barreiras de cor nos palcos brasileiros, como também formou a primeira geração de atores e atrizes negras da dramaturgia brasileira.

Dando um salto nos diversos aspectos que compõe sua trajetória, vale ressaltar que com a promulgação do Ato Institucional número 5, durante a ditadura militar, sendo alvo de vários inquéritos Policial-Militares, Abdias fica 12 anos em exilio e ao retornar ao Brasil participa do processo de redemocratização do país, ajudando a criar o PDT (Partido Democrático

\footnotetext{
${ }^{11}$ Para mais informações biográficas de Abdias, visitar o site do Instituto de Pesquisas e Estudos Afro-BrasileirosIPEAFRO. Disponível em < http://ipeafro.org.br/personalidades/abdias-nascimento/> .
} 
Trabalhista). Anos após, foi deputado (1983 a 1987) e senador federal (1997 a 1999) do Rio de Janeiro, tendo como uma das principais pautas a criação de políticas públicas afirmativas de igualdade racial.

Sua agência política é do tamanho de sua vida, logo não é meu intuito descrever todos os feitos de nosso filósofo político, contudo, é importante sabermos que Abdias, até os seus 97 anos, dedicou sua vida na luta pelo reconhecimento da humanidade, direito à cidadania, liberdade e igualdade para população negra.

Em vida, Abdias Nascimento expressou o desejo de que, ao desencarnar, suas cinzas fossem levadas à Serra da Barriga, local reconhecido como o antigo Quilombo dos Palmares, palco da construção da vida em liberdade dos africanos e seus descentes no Brasil. Desejo realizado em 13 de novembro de 2011 com uma bela e emocionante cerimônia, onde organizações da sociedade civil do Brasil e do mundo estiveram presentes.

E o que isso nos importa? Essa informação importa para que tenhamos compreensão do amor e importância que Abdias dava ao território que representa, para a população negra, o local onde foi possível construir uma vida em liberdade. Os Quilombos, genuínos focos de resistência física e cultural dos descendentes de africanos que se recusavam à violência e submissão a um modo de vida escravista, são para o filósofo, o maior acervo onde podemos encontrar referencias úteis e positivas para o fortalecimento da nossa caminhada rumo à emancipação.

Sejam os quilombos legalizados ${ }^{12}$ (associações, irmandades, confrarias, grêmios, escolas de samba, afoxés, terreiros, etc) como os quilombos "ilegais", ambos "foram uma unidade, uma única afirmação humana, étnica e cultural, a um tempo integrando uma prática de libertação e assumindo o comando da própria história"(NASCIMENTO, 2019,p.282).Por este fato, o filósofo conceitua por Quilombismo todo este complexo de significações e práxis afro-brasileira.

Em 1980 Abdias lança, portanto, a obra O Quilombismo, composta de 10 ensaios produzidos em tempo-espaços diferentes, que podemos considerar ser a "escrevivência" de um ativista e político negro, exposto na trincheira, para transformar a vida da população negra no Brasil racista (MUNANGA, 2019). Com a seguinte dedicatória, o autor abre a obra:

Em memória dos trezentos milhões de africanos assassinados por escravistas, invasores, saqueadores, torturadores e supremacistas brancos;

\footnotetext{
${ }^{12}$ Aceitos pela sociedade dominante.
} 
Dedico este livro aos jovens negros do Brasil

e do mundo, continuidade da luta por um tempo de justiça, liberdade e igualdade onde os crimes

do racismo não possam jamais se repetir

Com amor fraterno do

AUTOR.

Essa dedicatória possui um simbolismo extraordinário para mim, pois enquanto uma jovem negra, pesquisadora de uma filosofia afroperspectivista que faça sentido para minha coletividade, que nos reconheça como humanos, detentores de racionalidade e agência política; me sinto a continuidade da luta por um tempo de justiça, liberdade e igualdade para que os meus, no agora e no futuro não sofra o que nossos ancestrais sofreram e eu ainda sofro.

E este, para mim, é o sentido desta obra. Sobretudo, do documento 7 titulado “Quilombismo”. Nele, compreendo que há uma filosofia afroperspectivista, um projeto de sociedade, um projeto de futuro autêntico pra população negra, que parte de uma referência política que não é fruto de uma maquinação mental, falsa e abstrata. Muito menos tem princípios importados de contextos diferentes.

Para Abdias, nossa filosofia, assim como nossos princípios e estratégias políticas deve advir da cultura e da práxis da coletividade negra. Por essa ideia alimentar o filósofo, um dos objetivos da obra consiste em nos ajudar a compreender que "Para o restabelecimento da integridade de nossa família - a família africana, no continente e fora dele -, é imprescindível o reforço dos nossos vínculos ideológicos e culturais como condição prévia de nosso sucesso" (NASCIMENTO, 2019, p.37).

Nesta perspectiva, para que isso aconteça é imprescindível a destruição do projeto de sociedade que o Ocidente nos legou. Abdias é consciente do rígido monopólio do poder político e da concentração racial dos recursos pela branquitude, que é minoria no Brasil, e permanece nos governando, desde os tempos coloniais, como se isso fosse algo natural, um direito democrático, considerado justo pela intelligentsia brasileira.

Dado esse modus operandi da branquitude racista e tendo testemunhado nos diversos movimentos negros a ocorrência da cooptação branca das organizações e dos indivíduos negros e seus objetivos, buscando desintegrá-las e estimulando traição e exploração da comunidade negra pela esquerda branca, Abdias compreende que a luta pela emancipação do povo negro e indígena só ocorrerá através da autogestão e autodeterminação destes povos.

Compreende que o negro só "poderá ter um futuro melhor quando houver a 
transformação de toda estrutura do país, em todos seus níveis: na economia, na sociedade, na cultura, na política." (NASCIMENTO, 2019, p.42). Como também, entende e afirma que necessitamos produzir a nossa intelligentsia, pois

Um futuro de melhor qualidade para a população afro-brasileira só poderá ocorrer pelo esforço enérgico de organização e mobilização coletiva, tanto da população negra como das suas inteligências e capacidades escolarizadas, para a enorme batalha no fronte da criação teórico-cientifica. Há de se consolidar uma teoria cientifica inextricavelmente fundida à nossa pratica histórica que efetivamente contribua à salvação da comunidade negra, a qual vem sendo inexoravelmente exterminada seja pela matança direta da fome, seja pela miscigenação compulsória, seja pela assimilação do negro aos padrões e ideais ilusórios do lucro ocidental (NASCIMENTO, 2019, pp. 290291).

Urge, para Abdias, que nós codifiquemos nossa experiencia por nós mesmos e tiremos dessa experiencia de elaboração, interpretação e sistematização da história, as lições teóricas e práticas que interessa a população negra para a resolução de suas demandas e de sua respectiva visão de futuro, para que não continuemos executando projetos de futuro impostos.

Sua parte nesse processo ele fez. O documento 7 denominado $O$ Quilombismo é, ao meu ver, o início da edificação de uma ciência histórico-humanista do povo negro, por sistematizar um projeto de Estado Nacional Quilombista, inspirado nas organizações quilombolas que tem como o eixo a Liberdade e a Igualdade, a autodeterminação e autogestão do negro.

É uma filosofia que sistematiza e expõe o agenciamento político negro ao evidenciar que os negros sempre quiseram, querem e podem arquitetar, consciente e consistentemente, um outro projeto de sociedade, antagônico ao projeto ocidental, capitalista e racista. Vejamos o projeto apresentado por Abdias. Diz o autor:

O negro tragou até à última gota os venenos da submissão imposta pelo escravismo, perpetuada pela estrutura do racismo psicossócio-cultural que mantém atuando até os dias de hoje. Os negros tem como projeto coletivo a ereção de uma sociedade fundada na liberdade, na justiça, na igualdade e no respeito a todos os seres humanos; uma sociedade cuja natureza intrínseca torne impossível a exploração econômica e o racismo; uma democracia autêntica, fundada pelos destituídos e deserdados deste país, aos quais não interessa a simples restauração de tipos e formas caducas de instituições políticas, sociais e econômicas as quais serviriam unicamente para procrastinar o advento de nossa emancipação total e definitiva, que somente pode advir com a transformação radical das estruturas vigentes. Cabe mais uma vez insistir: não nos interessa a proposta de uma adaptação aos moldes da sociedade capitalista e de classes. Esta não é a solução que devemos aceitar como se fora mandamento inelutável. Confiamos na idoneidade mental do 
negro, e acreditamos na reinvenção de nós mesmos e de nossa história. Reinvenção de um caminho afro-brasileiro de vida fundado em sua experiencia histórica, na utilização do conhecimento critico e inventivo de suas instituições golpeadas pelo colonialismo e pelo racismo. Enfim, reconstruir no presente uma sociedade dirigida ao futuro, mas levando em conta o que ainda for útil e positivo no acervo do passado. (NASCIMENTO, 2019, p.288).

Verifica-se nesta passagem as características da sociedade almejada pelo povo preto. $\mathrm{O}$ projeto esboçado por Abdias é um projeto de revolução que é fundamentalmente antiautoritário, antirracista, anticapitalista, anti-imperialista, antineocolonialista, antiburocrata, antilatifundiária. Combate todos os tipos de governanças sociais e institucionais que visam procrastinar o advento da emancipação e fazer com que a população negra se adeque aos moldes da sociedade capitalista e de classes que estão assentadas no racismo.

O projeto do povo negro é fundado na liberdade, na justiça, na igualdade e no respeito a todos seres humanos e é por isso que seu nome advém da única organização que possibilitou o negro experimentar a liberdade: os quilombos, pois tanto o Estado colonial português quanto o Brasil - colônia, império e república - foi um estado de terror organizado contra a população negra.

Portanto, ratifico ser o quilombo o acervo que Abdias se volta para se inspirar e recuperar o que é útil e positivo para a construção e implementação de um projeto de sociedade que ele denomina como Estado Nacional Quilombista. Os quilombos, para o filósofo, em especial, A República de Palmares, no século XVI, nos legou um patrimônio de prática quilombista que possui um valor dinâmico na estratégia e na tática de sobrevivência e progresso das comunidades negras.

Na obra $O$ genocídio do negro brasileiro, Abdias salienta sobre a importância política de Palmares:

Em toda a história dos africanos no Novo Mundo nenhum acontecimento é tão excepcional quanto aquele que se registra no século XVI: a República dos Palmares, verdadeiro estado africano constituído no seio das florestas de Alagoas por rebeldes e fugitivos escravos. Desde 1630 até 1697, a chamada "Troia Negra" resistiu a mais de 27 expedições militares enviadas por Portugal e pelos holandeses, até que finalmente foi destruída pela força mercenária comandada por um bandeirante. Palmares - cuja população, se calcula, chegou à casa das trinta mil pessoas entre homens, mulheres e crianças possuía uma sociedade organizada com eficaz sistema de produção comunal e de trocas; sua organização defensiva, bem como a liderança política e militar, demonstram notável capacidade. A longa duração de Palmares testemunha a seu favor e a dos seus líderes, o último deles tendo sido o rei 
Zumbi; representa a primeira e heroica manifestação de amor à liberdade em terras do Brasil. (NASCIMENTO, 2017, p.72)

Vale lembrar que quilombo "não significa escravo fugido. Quilombo quer dizer reunião fraterna e livre, solidariedade, convivência, comunhão existencial” (NASCIMENTO, 2019, pp.289-290). E essa comunhão, nasce da exigência vital dos povos escravizados por liberdade, dignidade e uma organização social livre onde possam ser felizes. Por este fato, ao listar alguns princípios e propósitos deste projeto de sociedade, na obra $O$ Quilombismo, encontramos no $3^{\circ}$ princípio que,

A finalidade básica do Estado Nacional Quilombista é a de promover a felicidade do ser humano. Para atingir sua finalidade, o Quilombismo acredita numa sociedade de base comunitário-cooperativista no setor da produção, da distribuição e da divisão dos resultados do trabalho coletivo. (NASCIMENTO, 2019, p.305)

Esse princípio demonstra um dos caracteres mais revolucionários do projeto apresentado na obra. O Quilombismo reivindica como sistema econômico o comunitarismo ou ujamaaísmo da tradição africana, onde as relações de produção diferem do modelo de economia espoliativo (capitalista) fundado na lógica do lucro. É um projeto que combate a propriedade privada da terra, dos meios de produção, por defender que todos os fatores e elementos básicos são de propriedade e uso coletivo.

Também, defende que os trabalhadores, que produzem as riquezas são os únicos donos do produto de seu trabalho. Para além disso, são apresentados na obra, dezesseis princípios e propósitos chaves do Quilombismo que estruturam o projeto de Abdias de implementação de um Estado Nacional Quilombista, que devido os limites do trabalho, não cabe a apresentação de todos. Mas, vale fazer algumas considerações:

É evidente que Abdias apresenta-nos um projeto de sociedade e/ou Estado com base na autodeterminação da população negra que tem como exemplo inspirador o Quilombo dos Palmares, que traz uma proposta comunalista tradicional de alguns povos do continente africano, que demonstra a inexistência da relação exploradores e explorados.

Projetar uma sociedade que tem como base o comunalismo africano atualizado significa propor um projeto de futuro revolucionário para todxs nós, que está comprometido com a emancipação e real conquista da liberdade dos povos pretos e indígenas que são, historicamente, explorados e subtraídos do direito à terra, a moradia, à uma alimentação adequada, há um mundo habitável, ao trabalho digno, dado o sistema econômico capitalista neoliberal que 
massacra a população negra e indígena, por servir unicamente para garantir as riquezas advindas da escravização e expropriação das riquezas das terras dos povos colonizados.

Além de tudo, o projeto proposto pelo filósofo ao deslocar o ocidente do centro e evocar Palmares, e as organizações quilombolas como referência, propondo caminhos criativos e possíveis de vivência, torna-se um projeto com possibilidades reais de realização, pois não se

ampara em algo ideal, abstrato. É pautado em organizações sociais que existiram e resistiram, por anos ao modelo espoliativo.

Logo, é um projeto revolucionário que deve ser, sobretudo, pela filosofia política brasileira alcançado, analisado, proposto se é que queremos de fato pensarmos e projetarmos futuros que: não exista privilégios econômicos, políticos, culturais e sociais; que combata o genocídio, o epistemicídio e o mentecídio, resgate a memória e o agenciamento político dos povos negros e indígenas; contribua no processo de reontologização dos povos colonizados e caminhe rumo à emancipação dos povos subalternos.

Fato é que os princípios e propósitos do Quilombismo são revolucionários, também, por ser um projeto de Estado que não tem, em sua essência, condicionantes para a existência de uma Estadolátria que, em suma, somente em uma sociedade pautada na desigualdade e na propriedade privada dos recursos, estimula-se.

O projeto de futuro, de sociedade, que é arquitetado e fora, brevemente, esboçado aqui, tem o intuito de evidenciar e apresentar ao leitor/leitora que um projeto que, em sua essência, busca a autoderminação, autogestão do povo negro, que combate a supremacia branca, o imperialismo, o capitalismo, o autoritarismo, o neocolonialismo é um projeto possível, pois Palmares existiu e resistiu ao sistema supremacista branco e nós, organizados como nossos ancestrais, também podemos fazer outros Palmares!

\section{Considerações Finais}

Não é à toa que as governanças políticas e, por sua vez, econômica e ideológica apostou em um projeto de sociedade que, em primeira instância, buscasse apagar a nossa memória pelo mentecídio e epistemicídio, pois sábios e medrosos que são, estes arquitetos tem consciência que se $54 \%$ da população brasileira resgatar sua memória revolucionaria, sua autoestima, autoconfiança e se formarem politicamente, não há projeto ocidental que se mantenha.

O povo indígena e o povo negro são os artífices deste país! É dever da filosofia, em especial, política se comprometer em investigar, resgatar, sistematizar e apresentar outros 
paradigmas sociais e se empenhar a não retroalimentar e fortalecer propostas de mundo que, em suma, servem ao eterno projeto colonial europeu.

Afinal, até quando vamos ratificar teorias que negam a humanidade de povos que construíram a filosofia, ciência e a tecnologia e possuem uma cosmopolítica solidária, para servirmos a um projeto econômico que não nos considera e só existe por se apropriar, violentamente, dos nossos recursos?

Mais que nunca, amparada na filosofia ngoenhiana, acredito ser tempo da filosofia brasileira se reconciliar com a cultura, com o substrato cultural do nosso país e resgatar práticas de organização que tornem possível o amanhã, pois o genocídio que assola as famílias pretas/pobres é consequência de um projeto de sociedade que o lado esquerdo e o direito fazem parte de um mesmo corpo, o Estado.

E, esse projeto de Estado não é por nós. É contra nós. Logo, enquanto uma pesquisadora de filosofia afroperspectivista acredito que o Quilombismo é uma proposta organizacional revolucionaria que precisa chegar, interdisciplinarmente, na população preta dentro e fora das universidades.

A filosofia afroperspectivista pode e deve ser instrumento de investigação, recuperação, proposição e divulgação de vias, verdadeiramente, libertárias. E é por isso que apresento $O$ Quilombismo para que, como Abdias e José Carlos Limeira (poeta), saibamos que é possível construirmos um outro projeto de mundo e de sociedade, mas é preciso que olhemos nosso processo histórico e ousemos partir do sul, para que tenhamos Palmares como farol e possamos dizer que:

Por menos que conte a história

Não te esqueço meu povo

Se Palmares não vive mais

Faremos Palmares de novo

José Carlos Limeira

\section{Referências bibliográficas}

CARDOSO, Lourenço. A branquitude acrítica revisitada e a branquidade. Revista da ABPN, Florianópolis, v. 6, n. 13,p. 88-106, mar./jun. 2014.

CARNEIRO, Sueli Aparecida. A construção do Outro como Não-Ser como fundamento do Ser. Tese (Doutorado em Educação), Faculdade de Educação, Universidade de São Paulo, São Paulo, 2005. 339p. Disponível em < https://negrasoulblog.files.wordpress.com/2016/04/a- 
construc3a7c3a3o-do-outro-como-nc3a3o-ser-como-fundamento-do-ser-sueli-carneirotese1.pdf> Acesso 01 jun. 2019

DE MORAES, Wallace. Governados por quem? Diferentes plutocracias nas histórias políticas de Brasil e Venezuela. Curitiba: Editora Prismas, 2018.

DUPUIS-DÉRI, Francis. Quem tem medo do povo? O debate entre Ágora-fobia Política e Ágora-filia Política. Revista Estudos Libertários (REL), UFRJ, vol.1. Disponível em < https://revistas.ufrj.br/index.php/estudoslibertarios/article/view/24084/13884> Acesso em 22 mai. 2019.

LIMEIRA, Jose Carlos. Insônias. Disponível em $<$ http://leituraspretas.blogspot.com/2014/11/jose-carlos-limeira-paginas-negras.html $>$ Acesso 10 jun. 2019.

NASCIMENTO, Abdias do. O Quilombismo. Petrópolis: Vozes, 1980.

O Quilombismo. São Paulo: Editora Perspectiva, Rio de Janeiro: Ipeafro, 2019.

NGOENHA, Severino Elias. Os tempos da filosofia: filosofia e democracia moçambicana. Maputo. Imprensa Universitária, 2004.

África, 1993.

Filosofia africana das independências às liberdades. Maputo. Edições Paulistas -

NOGUERA, Renato. O Ensino de Filosofia e a Lei 10.639. Rio de Janeiro: CEAP, 2011.

- infantilização, ubuntu e teko porã: elementos gerais para educação e ética afroperspectivistas. Childhood \& Philosophy, Rio de Janeiro, v. 14, n. 31, set.-dez. 2018, pp. 625-644. Disponível em< https://www.epublicacoes.uerj.br/index.php/childhood/article/view/36200/26377> Acesso em 30 jun.2019.

SANTOS, Gislene Aparecida dos. A invenção do "ser negro": um percurso das ideias que naturalizaram a inferioridade dos negros. São Paulo: Educ/Fapesp, Rio de Janeiro: Pallas, 2002, 176p. 